
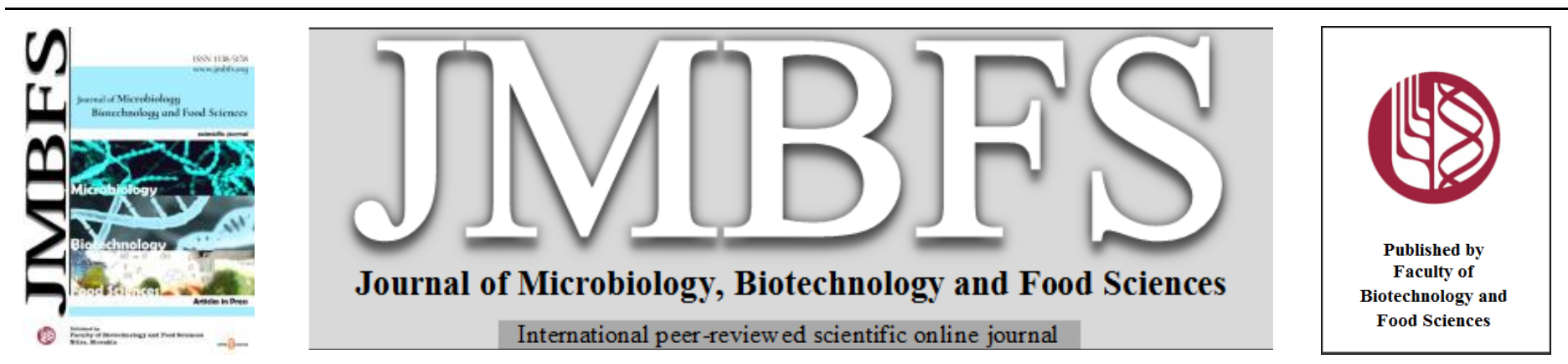

\title{
CONTROL OF THERMOPHILIC SPORES BY SPORICIDAL AGENTS AND THERMAL INACTIVATION
}

\author{
Ayse Busra Karakaya ${ }^{I}$, Basar Karacal, Birgul Ozcan ${ }^{2}$ and Arzu Coleri Cihan ${ }^{* 1}$
}

\author{
Address(es): Arzu Coleri Cihan, \\ ${ }^{1}$ Ankara University, Faculty of Science, Department of Biology, 06100, Ankara, Turkey. \\ ${ }^{2}$ Mustafa Kemal University, Science and Letters Faculty, Biology Department, 31001, Hatay, Turkey.
}

*Corresponding author: arzucoleri@gmail.com

https://doi.org/10.55251/jmbfs.4588

\section{ARTICLE INFO}

Received 18.3.2021

Revised 5. 1. 2022

Accepted 19. 1.2022

Published 1. 6. 2022

Regular article

OPEN $\partial_{\text {ACCESS }}$

\begin{abstract}
In this study, the adhesion patterns of thermophilic spores of Geobacillus thermodenitrificans DSM $465^{\mathrm{T}}$, Geobacillus thermoglucosidans B84a, Anoxybacillus kamchatkensis subp. asaccharedens F81 and Anoxybacillus flavithermus DSM $2641^{\mathrm{T}}$, all of which are biofilm producers in dairy products, were investigated by epifluorescence microscopy on 6 different abiotic surfaces commonly used in the dairy industry. The spores of G. thermodenitrificans DSM $465^{\mathrm{T}}$ and A. kamchatkensis subp. asaccharedens F81 were found to adhere mainly to rubber, polycarbonate, PTFE and stainless steel surfaces. In addition, the efficacy of sporicidal agents on the spores of these bacteria was investigated and only peracetic acid, cetylpyridinium chloride and formaldehyde were found to be the most effective of the sporicidal agents tested. Among the sporicidal agents that showed high efficacy against spores, peracetic acid and nitric acid were selected because they had the shortest contact time, low toxicity and cost. Binary combination effects were tested by determining the LD50 values of the selected agents and it was found that there was a synergistic effectbetween these two effective chemicals. In addition, the thermal resistance profiles of planktonic and sessile spores of A. flavithermus DSM $2641^{\mathrm{T}}$ and $G$. thermodenitrificans DSM $465^{\mathrm{T}}$ were evaluated.
\end{abstract}

Keywords: Anoxybacillus, Biofilm, Endospore, Geobacillus, Thermophilic bacteria, Sporicidal agent

\section{INTRODUCTION}

Thermophilic bacilli can develop and survive at high temperatures and are capable of forming spores and biofilms. These characteristics are common in some industrial environments, such as the dairy and fruit juice industries (Burgess et al. 2010). Species belonging to the genus Geobacillus and Anoxybacillus are mostly isolated from factories where dairy products are manufactured (Murphy et al., 1999; Flint et al., 2001a,b; Ronimus et al., 2003; Scott et al., 2007; Burgess $e$ al., 2010; Palmer et al., 2010). Thermophilic bacilli and their spores are commonly found on heat exchanger plates, cream separators, evaporator preheaters and evaporators (Murhpy et al., 1999; Refstrup, 2000; Scott et al., 2007; Yuan et al., 2012).

The spores of thermophilic bacilli can survive in heat treatment processes such as pasteurization and sterilization. The existence of the spores in such environments indicates poor hygiene (Muir et al., 1986; Burgess et al., 2009). Since they can form biofilms in industrial environments with heat treatment and multiply in a short time, thermophilic bacilli can be easily transferred to final products, and the presence of thermophilic biofilms in these environments leads to continuous contamination (Flint et al., 1997). Because spores are inherently more hydrophobic than vegetative cells, they can adhere more readily to surfaces (Husmark and Roenner, 1992). Spores adhering to surfaces can transform into vegetative forms under suitable environmental conditions, and these vegetative cells can develop into a thermophilic biofilm (Scott et al., 2007). If adequate cleaning application is not performed, this cycle causes continuous contamination in the environment where the products are processed. This continuous contamination leads to clogging of the hoses used in the production phase, prolongation of production time, corrosion of the surfaces, reduction of heat on the heat exchanger plates and indirect deterioration of the heat treatment used in sterilization (Parkar et al., 2004). Therefore, the removal efficiency of the chemical cleaning process is essential.

The antimicrobial and sporicidal properties of disinfectants and cleaning-in-places (CIP) procedures commonly used in the food industry have been demonstrated in studies on both thermophiles and mesophiles (Sykes, 1970; Russell, 1990; Te Giffel et al., 1995; Flint et al., 1997; Hinton et al., 2002). Spores are more difficult to remove with disinfectants than vegetative cells (Sykes, 1970). Due to their more complex and durable structure, endospores prove to be more resistant to chemical and physical agents than vegetative cells (Russell, 1998).
In this study, the thermal resistance of biofilms and spores of Geobacillus and Anoxybacillus was investigated. The resistance of their spores to various sporicidal-disinfectant agents was evaluated so comprehensively for the first time. The adhesion properties of these thermophilic bacilli spores were determined on surfaces made of $316 \mathrm{~L}$ stainless steel, polycarbonate, polypropylene, polyvinyl chloride, polytetrafluoroethylene (PTFE) and rubber, all of which are commonly used in the food industry.

\section{MATERIAL AND METHODS}

\section{Microbial strains}

In this study, four endospore-forming thermophilic bacilli known to be potential biofilm formers in dairy environments were preferred (Karaca et al., 2019, Karaca and Cihan, 2020). These species are Geobacillus thermodenitrificans DSM 465 ${ }^{\mathrm{T}}$, Geobacillus thermoglucosidans B84a, Anoxybacillus flavithermus DSM $2641^{\mathrm{T}}$ and Anoxybacillus kamchatkensis subsp. asaccharedens F81.

\section{Stimulation of sporulation}

DSM1X (Nutrient Broth $8 \mathrm{~g} / \mathrm{L}, \mathrm{KCl} 1 \mathrm{~g} / \mathrm{L}, \mathrm{MgSO}_{4} .7 \mathrm{H}_{2} \mathrm{O} 0.25 \mathrm{~g} / \mathrm{L}$ and $1 \mathrm{~mL}$ of 1 $\mathrm{M} \mathrm{Ca}\left(\mathrm{NO}_{3}\right)_{2}, 1 \mathrm{~mL}$ of $0.1 \mathrm{M} \mathrm{MnCl}_{2} \cdot \mathrm{H}_{2} \mathrm{O}, 1 \mathrm{~mL}$ of $1 \mathrm{mM} \mathrm{FeSO}_{4}$, and $2 \mathrm{~mL}$ of $50 \%$ glucose solution for 1 liter of media), DSM2X, and TBL $\left(\mathrm{K}_{2} \mathrm{HPO}_{4} 4.35 \mathrm{~g} / \mathrm{L}\right.$, $\mathrm{KH}_{2} \mathrm{PO}_{4} 3.4 \mathrm{~g} / \mathrm{L}$, tryptone $7.5 \mathrm{~g} / \mathrm{L}$, glucose $1 \mathrm{~g} / \mathrm{L}$ ) media were tested for stimulation of spore formation. Furthermore, these media contents were additionally supplied with L-glutamic acid, which plays a key role in the sporulation process (Donnellan et al., 1964). Twelve combinations of these three basic media were prepared with or without the addition of glucose and L-glutamic acid (TBL, TBL + glucose, TBL + L-glutamic acid, TBL + glucose+L-glutamic acid DSM 1X, DSM1X + glucose, DSM $1 \mathrm{X}+$ glucose, DSM1X + glucose + L-glutamic acid, DSM 2X, DSM2X + glucose, DSM 2X + L-glutamic acid, DSM2X + glucose + L-glutamic acid).

The strains were first inoculated into TSA (Tryptic Soy Agar) medium and then incubated under static conditions at $60^{\circ} \mathrm{C}$ for $18 \mathrm{~h}$. The strains were then incubated in TSA medium. After incubation, the culture was harvested and suspended in $0.85 \% \mathrm{NaCl}$ to obtain an optical density between 0.2 and 0.4 at $600 \mathrm{~nm}$. Finally, the suspended cultures were inoculated in $5 \mathrm{~mL}$ of sporulation medium at a ratio of $4 \%$ and then incubated at $60{ }^{\circ} \mathrm{C}$ for 24 and $48 \mathrm{~h}$ at $120 \mathrm{rpm}$. After incubation, 1 
$\mathrm{mL}$ of each culture suspension was harvested $\left(6000 \mathrm{rpm}, 15 \mathrm{~min}, 4^{\circ} \mathrm{C}\right)$ and the pellets were resuspended in $1 \mathrm{~mL}$ of isotonic solution. These suspensions were heat treated at $100{ }^{\circ} \mathrm{C}$ for $15 \mathrm{~min}$ to eliminate vegetative cells. The heat-treated suspensions were then diluted 10 -fold and each dilution was counted on TSA plates (Tryptic Soy Agar, Merck, Germany) using the spread-plate method.

\section{Production of the spore-stock}

To obtain a large number of spores, the ideal sporulation medium was used. 100 $\mathrm{mL}$ of the appropriate sporulation medium was inoculated for each strain at the $4 \%$ inoculation rate. The culture suspensions were incubated at $60^{\circ} \mathrm{C}, 120 \mathrm{rpm}$ for 24 and $48 \mathrm{~h}$, respectively. At the end of incubation, cultures were harvested at 6000 rpm for $15 \mathrm{~min}$ at $4{ }^{\circ} \mathrm{C}$. The pellets were sonicated $(40 \%$ amplitude, 0.6 cycles, 2 $\min )$ and then washed with physiological saline $\left(6000 \mathrm{rpm}, 15 \mathrm{~min}, 4{ }^{\circ} \mathrm{C}\right)$. The resulting pellets were again dissolved in $2 \mathrm{~mL}$ of physiological saline. The cellspore suspensions were layered on $10 \mathrm{~mL}$ of $55 \%$ sucrose solution and centrifuged at $4000 \mathrm{rpm}$ for $10 \mathrm{~min}$ to obtain cell-free spore stocks. The cell-free spores were stored and used for further studies. Spore counts were performed using the spread plate method, and the total number of spores was determined for each stock.

\section{Spore adhesion assay on different abiotic surfaces}

In this study, six abiotic surfaces were preferred to evaluate the spore adhesion properties of thermophilic bacilli. These surfaces are polypropylene, polycarbonate, polyvinyl chloride, stainless steel, PTFE (polytetrafluoroethylene or Teflon) and rubber (all in circular shape; $\mathrm{r}: 7 \mathrm{~mm}$ ).
The previously prepared spore stocks were diluted in physiological saline to 10 spores $/ \mathrm{mL}$. Two pieces of 6 surfaces were exposed to $5 \mathrm{~mL}$ of the adjusted spore suspension for $30 \mathrm{~min}$ at room temperature. After incubation, the surfaces were washed with sterile distilled water and the unbound spores were removed. One of the surfaces was used for spore counting. Spore counting was performed for each surface examined microscopically and the results were converted to $\log _{10} / \mathrm{cm}^{2}$. The other surface was soaked in $0.001 \%$ acridine orange solution (prepared in $100 \mathrm{nmol}$ phosphate buffer, pH: 7.2; Sigma-Aldrich, USA, 235474-5G, excitation/emission values-RNA; $460 / 650 \mathrm{~nm}$, DNA; $500-526 \mathrm{~nm}$ ) for $3 \mathrm{~min}$. The stained surfaces were washed 3 times with sterile distilled water to remove excess stain, analyzed at 20× magnification in a Zeiss MTB 2004 epifluorescence microscope, and photographed with a Zeiss Axiocam MRc5 camera. AxioVision Release 4.3 software (11-2004) was used to acquire the images

\section{Effects of sporicidal agents}

The sporicidal agents used are listed in Table 1 . The sporicidal activity test was carried out in 96-well microtiter plates (LP Italiana, Italy) to evaluate the effect of the sporicidal agents on thermophilic spores. A maximum treatment time of $30 \mathrm{~min}$ was selected as contact time for each agent $(1,2,5,10,15,20,25$ and $30 \mathrm{~min})$. The concentration values used in the experiment were doubled in cases where the recommended concentrations did not result in effective removal of spores. However, in the cases where the efficacy of the agent could not be established at increased concentration, no further increase in concentration was tested and it was assumed that the agent evaluated was not sufficient to remove the spores of the bacteria tested.

\begin{tabular}{cccc} 
Table 1 Sporicidal agents used in this study & $\begin{array}{c}\text { Concentrations used } \\
\text { in the literature }\end{array}$ & $\begin{array}{c}\text { Concentrations used in this } \\
\text { study }\end{array}$ & References \\
\hline Sporicidal Agents & $0.4 \%(\mathrm{w} / \mathrm{v})^{\mathbf{a}}$ & $0.4 \%, 0.8 \%, 1.2 \%$ & Russell, 1990 \\
Chlorocrezol (4-chloro-3-methylphenol) & $0.5 \%$ & $0.5 \%, 1.0 \%, 1.5 \%$ & Russell, 1990 \\
Crezol (m-cresol) & $0.5 \%$ & $0.5 \%, 1.0 \%, 1.5 \%$ & Russell, 1990 \\
Phenol & $0.05 \%$ & $0.05 \%, 0.1 \%, 0.15 \%$ & Russell, 1990 \\
Chlorhexidine diacetate & $0.05 \%$ & $0.05 \%, 0.1 \%, 0.15 \%$ & Russell, 1990 \\
Cetylpyridinium chloride & $2.0 \%$ & $2.0 \%, 4.0 \%, 6.0 \%$ & Russell, 1990 \\
Glutaraldehyde & $4.0 \%-8.0 \%$ & $0.8 \%, 1.6 \%, 2.4 \%$ & Russell, 1990 \\
Formaldehyde & $20 \mathrm{ppm}^{\mathbf{b}}$ & $20 \mathrm{ppm}, 40 \mathrm{ppm}, 60 \mathrm{ppm}$ & Russell, 1990 \\
Hypochlorite & $1.0 \%$ & $1.0 \%, 2.0 \%, 3.0 \%$ & Marchand et al., 2012 \\
Nitric Acid (HNO $\left.\mathrm{H}_{3}\right)$ & $12.5-25.0 \mathrm{ppm}$ & $12.5 \mathrm{ppm}, 25 \mathrm{ppm}, 37.5 \mathrm{ppm}$ & Banner, 1995 \\
Iodine & $4.0 \%-15.0 \%$ & $4.0 \%, 8.0 \%, 12.0 \%$ & Banner, 1995 \\
Peracetic acid & $100-200 \mathrm{ppm}$ & $200 \mathrm{ppm}, 400 \mathrm{ppm}, 600 \mathrm{ppm}$ & Banner, 1995 \\
Chlorine dioxide & & &
\end{tabular}

Finally, $10^{5}$ spores $/ \mathrm{mL}$ of spore stock were produced from each bacterium prior to testing. Based on the recommended concentrations of the evaluated sporicidal agents, test wells were prepared on the plates for each contact time $(1,2,5,10,15$, 20,25 and $30 \mathrm{~min}$ ). $100 \mu \mathrm{L}$ of the active ingredient content was added to these wells, followed by $10 \mu \mathrm{L}$ of each of the spore suspensions. At the end of each contact time, $100 \mu \mathrm{L}$ of the contents were removed from the wells and neutralization was performed according to the chemical tested. These contents were subjected to serial dilution (10-fold), and $100 \mu \mathrm{L}$ of the dilutions were inoculated onto TSA plates. The plates were incubated at $60^{\circ} \mathrm{C}$ for $24 \mathrm{~h}$ and spore counts were performed. Log reductions (LR; log reduction) were calculated by subtracting the final counts from the initial spore counts. Percent log reduction was calculated using the following formula: $\left(1-10^{-\mathrm{LR}}\right) \times 100(\mathrm{LR} ; \log$ reduction).

\section{Combinative treatment of the most effective sporicidal agents}

In this study, two highly effective sporicidal agents were selected within the scope of the previous study. Two reference strains (G. thermodenitrificans DSM $465^{\mathrm{T}}$ and $A$. flavithermus $2641^{\mathrm{T}}$ ) displaying high resistance to the sporicidal agents were evaluated in this assay. The study was conducted using two strategies based on the selected sporicidal agents.

In the first approach, the application of the two most effective agents for both strains (G. thermodenitrificans DSM $465^{\mathrm{T}}$ and A. flavithermus $2641^{\mathrm{T}}$ ) was performed sequentially at their ideal concentrations. First, $100 \mu \mathrm{L}$ of the first agent was transferred into 96-well microtiter plate wells and the spores were treated according to the ideal contact time. After the first application, the second agent was applied to the wells at its effective concentration and the spores were treated again during the appropriate contact time. At the end of the second treatment, the contents were neutralized and serially diluted 10 -fold. Finally, each dilution was inoculated onto the TSA plates. The plates were incubated for $24 \mathrm{~h}$ at $60^{\circ} \mathrm{C}$. The colony forming unit was calculated and the log reductions were calculated according to the initial concentration.

In the second approach, the Chou-Talalay method was preferred to determine possible synergistic, antagonistic and additive effects in different combinations considering the ideal concentrations of sporicidal agents (Chou, 2010). The ChouTalalay method developed for the evaluation of active ingredient combinations is based on the "median effect" equation, which originates from the "mass-action" principle. The combination indices (CI) determined according to the Chou-Talalay theory allow the quantification of possible additive, synergistic and antagonistic interactions between 2 or more active substance combinations (CI: 1, additive effect; CI $<1$, synergism, CI $>1$, antagonism). First, a series of dilutions $(1,1 / 2$, $1 / 4,1 / 8,1 / 16,1 / 32,1 / 64,1 / 128$ ) were made considering the previously determined ideal concentrations of both agents ( $\mathrm{Tab} 2$ ). In this experimental setup, the ideal concentration of each agent was determined in $\mu \mathrm{g}$. $10 \mu \mathrm{L}$ of the spore suspension of each strain was added to the wells of the plate, and then $100 \mu \mathrm{L}$ of the agent with the corresponding concentrations was added to the wells. At the end of the contact periods, the previously mentioned steps were repeated and spore counts were performed. Based on the spore counts, Probit analysis was performed and LD50 values were calculated for both agents (SPSS 22.0, USA).

\begin{tabular}{lcccccccc} 
Table 2 Nitric acid and peracetic acid concentrations in the test setup \\
\hline Dilution & $\mathbf{1}$ & $\mathbf{1 / 2}$ & $\mathbf{1 / 4}$ & $\mathbf{1 / 8}$ & $\mathbf{1 / 1 6}$ & $\mathbf{1 / 3 2}$ & $\mathbf{1 / 6 4}$ & $\mathbf{1 / 1 2 8}$ \\
\hline Nitric acid $(\mu \mathrm{g})$ & $4239(3.0 \%)$ & 2119.5 & 1059.75 & 529.88 & 264.94 & 132.47 & 66.23 & 33.12 \\
\hline Peracetic acid $(\mu \mathrm{g})$ & $4600(4.0 \%)$ & 2300 & 1150 & 575 & 287.5 & 143.75 & 71.88 & 35.94 \\
\hline
\end{tabular}

In preparing different combinations, seven dual combinations were tested to consider the LD50 values of each agent (1st agent-2nd agent: 1:1, 1:2, 2:1, 1:3, $3: 1,1: 4,4: 1$; each ratio corresponds to the multiple of the LD50 of the agent). The reaction mixtures were prepared with the indicated combination ratios, and spore counts were performed at the end of the application as explained previously. As a result of the counting, the response effect values of the combined doses were 
calculated by considering the decrease in spore number (XLSTAT, 2015). Finally, isobolograms were generated according to the dose-response curves and reference lines of dual combinations and possible additive, synergistic and antagonistic interactions were determined using Compusyn software.

\section{Thermal inactivation of thermophilic spores}

To study the thermal inactivation profiles of spores in both biofilm and planktonic phases, boiling at $100{ }^{\circ} \mathrm{C}$ for 30 and $60 \mathrm{~min}$, sterilization at $121{ }^{\circ} \mathrm{C}$ for $15 \mathrm{~min}$ (autoclave), and processes partially corresponding to dry heat treatment $\left(130^{\circ} \mathrm{C}\right.$ and $140{ }^{\circ} \mathrm{C}$ treatment for $1,5,15,30$ and $60 \mathrm{~min}$ ) were applied to thermophilic spores. After the heat treatment applications at the indicated times, the samples were immediately cooled in ice. Moist heat uses water, so unlike dry heating methods, it does not cause dehydration. It also penetrates deeper into cells, making it far more effective than dry heat. This study was again carried out with the reference strains A. flavithermus DSM $2641^{\mathrm{T}}$ and G. thermodenitrificans DSM $465^{\mathrm{T}}$ due to their high resistance to sporicidal agents. Planktonic spores and the spores in biofilm samples not subjected to heat treatment were designed as positive control groups.

For thermal inactivation of planktonic spores, the spore stocks prepared at concentrations of $10^{7}$ spores $/ \mathrm{mL}$ were used. $1 \mathrm{~mL}$ of these suspensions were transferred to sterile glass tubes and the tubes were subjected to the indicated heat treatments. After the heat treatments, a series of dilutions were prepared and inoculation was performed on the TSA plates using the spread plate method. The plates were incubated at $55^{\circ} \mathrm{C}$ for $24 \mathrm{~h}$ and then spore counting was performed. Based on the log count results, the log reduction (LR; log reduction) was calculated as a function of the initial spore concentration.

$316 \mathrm{~L}$ stainless steel surfaces $(2.5 \times 0.8 \mathrm{~cm})$, commonly used in the dairy industry, were preferred for sporulation in the biofilm samples. 6-well cell culture plates were used for biofilm sampling. Biofilm sampling and inoculation preparation were performed based on the method proposed by Karaca et al. (2019). Two of the sterile steel surfaces were transferred to each well of the microtiter plate. Then, 5 $\mathrm{mL}$ of the milk samples previously mixed with $4 \%$ active cultures were transferred into the wells. The plates were incubated at $60^{\circ} \mathrm{C}$ for $48 \mathrm{~h}$. At the end of $24 \mathrm{~h}$, the milk content was renewed and the coupons were inverted. After the incubation period, the coupons were removed under aseptic conditions and washed twice with sterile saline to remove loosely adhering bacteria. After washing, the coupons of the control group (samples not subjected to any treatment) were transferred to Falcon tubes containing $4.5 \mathrm{~mL}$ of sterile saline and $10 \mathrm{~g}$ of glass beads (R: $3 \mathrm{~mm}$ ) The tubes were vortexed at maximum intensity for $2 \mathrm{~min}$. The prepared biofilm suspensions were boiled for $15 \mathrm{~min}$ to eliminate the vegetative cell forms of the spores. A series of 10 -fold dilutions were then performed and $100 \mu \mathrm{L}$ of the diluted samples were inoculated into TSA plates. At the end of the $24 \mathrm{~h}$ incubation at 55 ${ }^{\circ} \mathrm{C}$, the colonies were counted and converted to a logarithmic scale. These results are intended as a control for the number of spores in biofilm samples.

Stainless steel surfaces containing biofilm samples were transferred to glass test tubes containing $4.5 \mathrm{~mL}$ of sterile saline for boiling and autoclaving processes. The tubes were boiled for 30 and $60 \mathrm{~min}$ and autoclaved for $15 \mathrm{~min}$ at $121^{\circ} \mathrm{C}$. After boiling and autoclaving, the physiological saline and coupons in the tubes were transferred to new Falcon tubes containing $10 \mathrm{~g}$ sterile glass beads. The tubes were vortexed at maximum intensity for $2 \mathrm{~min}$. Final enumeration was performed by a dilution procedure from these contents.

Stainless steel coupons containing biofilm samples were also transferred to glass tubes containing $4.5 \mathrm{~mL}$ of sterile saline after washing, and the tubes were then held in a dry heat block at 130 and $140{ }^{\circ} \mathrm{C}$ for $1,5,15,30$, and $60 \mathrm{~min}$. At the end of the heat treatment, the contents of the tubes were transferred to Falcon tubes containing glass beads and vortexed. The biofilm suspensions were subjected to an additional boiling process to eliminate possible viable vegetative cell forms. After this process, the dilution and counting processes were performed. All spore count results were converted to a logarithmic scale.

\section{RESULTS AND DISCUSSION}

\section{Determination of the ideal sporulation medium}

After combination experiments for different sporulation media, the best sporulation medium and incubation conditions for the thermophilic bacilli in each case are given in Table 3. Under these conditions, spore counts of $\leq 10^{9}$ spores $/ \mathrm{mL}$ were achieved for all thermophilic endospore formers required for further experiments. It was also noteworthy that the ideal sporulation media for 4 of the thermophilic species were all different from each other during a $48 \mathrm{~h}$ incubation period.

Table 3 Ideal sporulation media and incubation conditions

\begin{tabular}{|c|c|c|}
\hline Reference strains/Isolates & Medium/Incubation conditions & Number of spores per $\mathrm{mL}$ \\
\hline A. flavithermus DSM $2641^{\mathrm{T}}$ & $\operatorname{DSM}^{\mathrm{a}} 2 \mathrm{X} / 60^{\circ} \mathrm{C}, 48 \mathrm{~h}$ & $10^{9}$ spores $/ \mathrm{mL}$ \\
\hline A. kamchatkensis subsp. asaccharedens $\mathrm{F} 81$ & TBL + L-Glutamic acid $/ 60{ }^{\circ} \mathrm{C}, 48 \mathrm{~h}$ & $10^{9}$ spores $/ \mathrm{mL}$ \\
\hline G. thermodenitrificans DSM $465^{\mathrm{T}}$ & DSM $1 \mathrm{X}^{\mathrm{b}}, 60^{\circ} \mathrm{C}, 48 \mathrm{~h}$ & $10^{10}$ spores $/ \mathrm{mL}$ \\
\hline G. thermoglucosidans B84a & DSM $2 \mathrm{X}^{\mathrm{c}}+$ Glucose $+\mathrm{L}-$ Glutamic acid, $60^{\circ} \mathrm{C}, 48 \mathrm{~h}$ & $10^{9}$ spores $/ \mathrm{mL}$ \\
\hline
\end{tabular}

Legend:a'DSM; Difco Sporulation Medium; ${ }^{\mathrm{b}} 1 \mathrm{X}$ : one-fold concentrated; ${ }^{\mathrm{c}}$ two-fold concentrated

The thermal resistance of bacterial spores can vary depending on the minerals and water activity in their environment (Beaman $\boldsymbol{e t}$ al., 1982). In addition, conditions such as temperature and $\mathrm{pH}$ of the environment in which sporulation occurs affect spore resistance (de Vries et al., 2004). Minerals such as magnesium, calcium and potassium also play an essential role in this process. These minerals are essential for the development of mature spores and promote sporulation (Vinter, 1970) Calcium accumulates in the core part of the spore at the beginning of spore formation. Calcium also increases the expression of genes that initiate sporulation (Oomes et al., 2009). Mineral salts are commonly used in sporulation media (Cooney and Freese, 1976; Kaul and Singh, 1982; Warriner and Waites, 1999). Since these minerals are also present in dairy products, they promote sporulation of thermophilic bacilli. The time required for sporulation in thermophilic bacilli varies among species and genera. For instance, while some thermophilic bacilli can be fully sporulated within a week in media supplied with minerals, some Geobacillus isolates can be sporulated for 12 to $18 \mathrm{~h}$ in standard Tryptic Soy Broth (TSB) supplied with minerals $\left(\mathrm{CaCl}_{2}, \mathrm{MnSO}_{4}, \mathrm{FeSO}_{4}\right.$, or $\left.\mathrm{MgCl}_{2}\right)\left(10^{5}-10^{7}\right.$ spores $\left./ \mathrm{mL}\right)$ (Seale et al., 2008). In this study, TBL, DSM1X and DSM2X media were used to promote sporulation of thermophilic bacilli. Among these media, TBL medium consists of $\mathrm{MgSO}_{4}, \mathrm{MnSO}_{4}, \mathrm{ZnSO}_{4}, \mathrm{FeSO}_{4}$ and $\mathrm{CaCl}_{2}$ These salts are commonly used in sporulation media to promote sporulation. DSM1X and DSM2X supplied with $\mathrm{Ca}\left(\mathrm{NO}_{3}\right)_{2}, \mathrm{MnCl}_{2}$ and $\mathrm{FeSO}_{4}$ were also investigated to promote sporulation. It was found that the requirements for sporulation differed according to the thermophilic species tested. Also, the high amount of calcium stimulated sporulation of 4 of the endospore formers Furthermore, in contrast to the study by Seale (2008), all the thermophilic bacilli used in that study were found to be highly sporulated only after $48 \mathrm{~h}$ of incubation (Tab 3).

\section{Adhesion of thermophilic spores on abiotic surfaces}

Adhesion patterns of thermophilic bacilli on six abiotic surfaces are shown in Supplementary File (Figure 1-6). As can be seen in fluorescence microscopy analysis, excessive irradiation was observed in the fluorescence spectrum of acridine orange especially on surfaces like polypropylene, polyvinyl chloride, polycarbonate (autofluorescence). Therefore, for such surfaces as polyvinyl chloride, the filter set20 Transmitter R Red filter (excitation; $\approx 546 \mathrm{~nm}$, emission $\approx 640 \mathrm{~nm}$ ) of the epifluorescence microscope was used during imaging and for al other abiotic surfaces the filter set10 Transmitter G Green filter (excitation; $\approx 450$ $490 \mathrm{~nm}$ ) emission $\approx 515-565 \mathrm{~nm}$ ) was used (Kepner and Pratt, 1994).

Based on these results, while the spores of $G$. thermodenitrificans DSM $465^{\mathrm{T}}$ mainly adhered to the rubber and polycarbonate surfaces, the spores of $G$ thermoglucosidans B84a mostly preferred Teflon and stainless steel surfaces. In addition, the spores of $A$. kamchatkensis subsp. asaccharedens F81 mostly adhered to Teflon and polyvinyl chloride surfaces, while the spores of $A$. flavithermus DSM $2641^{\mathrm{T}}$ mostly adhered to polycarbonate and stainless steel surfaces. The spores observed under epifluorescence microscope with diameters of about 1-2 $\mu \mathrm{m}$ produced a bright fluorescence image of single spores or spore clusters depending on the wavelength of light. The spore numbers also correlated with the microscopy images, and fluorescence illumination was also observed more intensely on these surfaces (Supplementary File, Figure 1-6). According to these results, the surfaces preferred by thermophilic spores were found to be different depending on the bacterial species.

Spores differ significantly from the attachment behavior of vegetative cells to surfaces because they are not metabolically active and immobile (Setlow, 2007). The adhesion properties of thermophilic bacteria to the surface have been determined in some previous studies (Flint et al., 1997; Seale, 2008). In related studies, surface hydrophobicity was reported to increase spore adhesion to surfaces. Adhesion of vegetative cells and spores to surfaces is a process involving many factors. Factors affecting the adhesion of bacteria to surfaces include the properties of the surface, the growth phase of the bacteria, the contact time with the surface, the temperature of the environment, the roughness of the surface, the chemical signaling between cells, and the cleanliness of the surface (Stickler, 1997; Flint et al., 1997). Cell surface electrical charge and hydrophobicity also influence bacterial adherence (Hood and Zottola, 1995). Spores with hydrophobic surface properties tend to adhere more strongly to stainless steel than vegetative cells. Proteins in milk cause both vegetative cells and spores to adhere more 
strongly to surfaces. In addition, the electrical charge and wettability of the surface can affect the ability of spores to adhere (Parkar et al., 2001). The relationship between surface topography and bacterial attachment has been studied over the las 45 years (Flint et al., 1997). Whitehead and Verran, (2007) have shown that the attachment pattern depends on surface topography and not chemistry. However, contrary to the findings of White and Verran's (2007) study, some studies have emphasized that surface chemistry significantly affects the attachment of spores and vegetative cells. Most of the surface materials (polycarbonate, polyviny chloride, polypropylene) preferred in dairy industry are mostly in polymeric structure. Although most of these polymeric materials are thermally, chemically and biologically stable, they are highly hydrophobic and accelerate protein absorption (Turkiewicz et al., 2006). Absorption of milk proteins on these surfaces increases hydrophobicity and facilitates attachment of bacterial cells and spores (Brooks and Flint, 2008). Palmer et al. (2010) also found that the adhesion patterns of vegetative cells and spores of A.flavithermus vary depending on surface type and chemistry.

In this study, the adhesion patterns of 4 different thermophilic bacilli spores on 6 surfaces were determined by examination under epifluorescence microscope. It was found that $A$. flavithermus DSM $2641^{\mathrm{T}}$ had the highest adhesion rate for all the surfaces tested. According to these results (Supplementary File, Figure 1-6), the spores of A. flavithermus DSM $2641^{\mathrm{T}}$ were found to be highly hydrophobic. While the spores of $G$. thermoglucosidans B84a had the highest adhesion rate on the rubber surface, the spores of G. thermodenitrificans DSM $465^{\mathrm{T}}$ had the highes adhesion rate on the Teflon surface. Based on these results, the adhesion rates of thermophilic spores on surfaces with different physicochemical properties vary at the species level. Based on the high adhesion capacity of A. flavithermus DSM $2641^{\mathrm{T}}\left(4.8-6.1 \log \mathrm{CFU} / \mathrm{cm}^{2}\right)$ and $G$. thermodenitrificans DSM $465^{\mathrm{T}}(4.0-5.7$ $\log \mathrm{CFU} / \mathrm{cm}^{2}$ ) on all surfaces, it can be assumed that the spores of these species can transform and develop as vegetative form, forming biofilms and thus causing continuous contamination of products in the dairy industry. The lowest adhesiveness was observed for the spores of A. kamchatkensis subsp asaccharedens F81 (3.3-4.1 $\log \mathrm{CFU} / \mathrm{cm}^{2}$ ) (Supplementary File, Figure 1-6).

\section{Effects of sporicidal agents on thermophilic spores}

The efficacy of some sporicidal agents in the food industry was tested according to the recommended concentrations and exposure times in the respective study (Tab1). On evaluation of the results, it was found that sporicidal agents such as chlorine dioxide, phenol and iodine eliminated only G. thermoglucosidans B84a spores. Chlorocresol eliminated the spores of A. kamchatkensis subsp asaccharedens F81. In addition, nitric acid eliminated all the spores of $A$ flavithermus DSM $2641^{\mathrm{T}}$, G. thermoglucosidans B84a and A. kamchatkensis subsp. asaccharedens F81 and $99.998 \%$ of the spores of G. thermodenitrificans DSM $465^{\mathrm{T}}$. Chlorhexidine diacetate eliminated $100 \%$ of the spores of $A$ flavithermus DSM 2641 ${ }^{\mathrm{T}}$, G. thermoglucosidans B84a, and A. kamchatkensis subsp. asaccharedens F81, and $99.993 \%$ of the spores of $G$. thermodenitrificans DSM $465^{\mathrm{T}}$ within the concentrations and contact times indicated. Complete removal of all thermophilic spores was achieved only by treatment with peracetic acid, cetylpyridinium chloride and formaldehyde.

Cumulative evaluation of the efficacy of the sporicidal agents against spores showed that the spores of strains $G$. thermodenitrificans DSM $465^{\mathrm{T}}$ and $A$ flavithermus DSM $2641^{\mathrm{T}}$ were much more resistant than the spores of $G$ thermoglucosidans B84a and A. kamchatkensis subsp. asaccharedens F81.

Of the sporicidal agents, only peracetic acid, cetylpyridinium chloride and formaldehyde had an absolute effect on the spores of 4 thermophilic species However, cetylpyridinium chloride, a quaternary ammonium compound used as a drug in some cases, is known to be toxic in high doses and is a very expensive chemical. Formaldehyde is also a toxic chemical in liquid form and can be carcinogenic. In this regard, peracetic acid can be considered as the least harmless agent among these 3 agents as it acts on the spores of 4 thermophilic species. When chlorhexidine diacetate and nitric acid, which are $100 \%$ effective against all spores, were compared, it was found that chlorhexidine diacetate will be more costly for clean-in-place (CIP) procedures in industrial environments. $4.0 \%$ peracetic acid and $3 \%$ nitric acid formulations effective against the spores of 4 thermophilic species were preferred due to their low toxicity to human and environmental health and low cost (Supplementary File, Tab 5-8).

\section{Combinative treatment of ideal sporicidal agents}

In the first strategy where nitric acid and peracetic acid were treated consecutively, all A. flavithermus DSM $2641^{\mathrm{T}}$, and G. thermodenitrificans DSM $465^{\mathrm{T}}$ resistant spores were eliminated. In the second strategy, an experimental design was performed to determine possible synergetic, additive, and antagonistic interactions between the 2 sporicidal agents. Accordingly, a series of dilutions were made first considering the previously determined ideal concentrations of both sporicidal agents [(3.0\% Nitric acid solution; $100 \mu \mathrm{L}$ in the reaction mixture: $4239 \mu \mathrm{g}),(4.0 \%$ Peracetic acid solution; amount in $100 \mu \mathrm{L}$ reaction mixture: $4600 \mu \mathrm{g})]$, (Tab 2). Based on the concentration values indicated in Table 2 and the contact times of both sporicidal agents, LD50 values were determined by Probit analysis for $G$. thermodenitrificans DSM $465^{\mathrm{T}}$ and A. flavithermus DSM $2641^{\mathrm{T}}$ spores (Tab 4 and Tab 5). A treatment design was performed in 7 binary combinations, considering the LD50 values of each sporicidal agent (30 min contact time of nitric acid), (Nitric acid-Peracetic acid; 1:1, 1:2; 2:1, 1:3, 3:1, 1:4, 4:1; each ratio corresponds to the multiples of the LD50 of the active substance). Reaction mixes were prepared with the combination ratios, and spore counts were performed at the end of the treatment, as explained previously. As a result of the counting results, the dose responses of evaluated agents were calculated considering the decreases in the spores (XLSTAT, 2015), (Tab 6).

Table 4 Effects of different nitric acid and peracetic acid concentrations on A. flavithermus DSM $2641^{\mathrm{T}}$ spores, and their LD50 values (Probit analysis)

\begin{tabular}{|c|c|c|c|c|}
\hline $\begin{array}{l}\text { Nitric acid concentrations } \\
(\mu \mathrm{g})\end{array}$ & $\begin{array}{l}\text { Initial spore concentration } \\
\log (\text { spore } / \mathrm{mL})\end{array}$ & $\begin{array}{c}\text { Spore counts after } \\
\text { treatment } \log (\text { spore } / \mathrm{mL})\end{array}$ & $\begin{array}{c}\text { Reduction per } \mathrm{mL} \\
\log (\text { spore } / \mathrm{mL})\end{array}$ & \multirow{9}{*}{$\begin{array}{l}\mathrm{LD}^{\mathrm{a}} 0^{\mathrm{a}} \\
1.801 \mu \mathrm{g}\end{array}$} \\
\hline 33.12 & 5 & 4 & 4.9542 & \\
\hline 66.23 & 5 & 3.954 & 4.9590 & \\
\hline 132.47 & 5 & 3.875 & 4.9661 & \\
\hline 264.94 & 5 & 3.531 & 4.9850 & \\
\hline 529.88 & 5 & 3.079 & 4.9948 & \\
\hline 1059.75 & 5 & 1.940 & 4.9996 & \\
\hline 2119.5 & 5 & 1.536 & 4.9998 & \\
\hline 4239 & 5 & 1.342 & 4.9999 & \\
\hline $\begin{array}{c}\text { Peracetic acid } \\
\text { concentrations }(\mu \mathrm{g})\end{array}$ & $\begin{array}{c}\text { Initial spore concentration } \\
\log (\operatorname{spore} / \mathrm{mL})\end{array}$ & $\begin{array}{c}\text { Spore counts after } \\
\text { treatment } \log (\text { spore } / \mathrm{mL})\end{array}$ & $\begin{array}{c}\text { Reduction per } \mathrm{mL} \\
\log (\text { spore } / \mathrm{mL})\end{array}$ & \multirow{9}{*}{$\begin{array}{l}\text { LD50 } \\
18.88 \mu \mathrm{g}\end{array}$} \\
\hline 4600 & 5 & 4.3617 & 4.88649 & \\
\hline 2300 & 5 & 4.0792 & 4.94448 & \\
\hline 1150 & 5 & 2.5185 & 4.99856 & \\
\hline 575 & 5 & 1.9085 & 4.99965 & \\
\hline 287.5 & 5 & 1.7404 & 4.99976 & \\
\hline 143.75 & 5 & 1.1761 & 4.99993 & \\
\hline 71.88 & 5 & 0.9031 & 4.99997 & \\
\hline 35.94 & 5 & 0.4771 & 4.99999 & \\
\hline
\end{tabular}

Legend:a'LD50: lethal dosage 50

Table 5 Effects of different nitric acid and peracetic acid concentrations on G. thermodenitrificans DSM $465^{\mathrm{T}}$ spores and their LD50 values (Probit analysis)

\begin{tabular}{cccc}
\hline $\begin{array}{c}\text { Nitric acid } \\
\text { concentrations }(\mu \mathrm{g})\end{array}$ & $\begin{array}{c}\text { Initial spore concentration } \\
\log (\text { spore } / \mathrm{mL})\end{array}$ & $\begin{array}{c}\text { Spore counts after } \\
\text { treatment } \log (\text { spore } / \mathrm{mL})\end{array}$ & $\begin{array}{c}\text { Reduction per mL } \\
\log (\mathrm{spore} / \mathrm{mL})\end{array}$ \\
\hline 33.12 & 5 & 4.322 & 4.898 \\
66.23 & 5 & 3.362 & 4.990 \\
132.47 & 5 & 2.778 & 4.997 \\
264.94 & 5 & 2.572 & 4.998 \\
529.88 & 5 & 1.623 & 5.000 \\
1059.75 & 5 & 0.000 & 5.000
\end{tabular}




\begin{tabular}{cccc}
2119.5 & 5 & 0.000 & 5.000 \\
4239 & 5 & 0.000 & 5.000 \\
\hline $\begin{array}{c}\text { Peracetic acid } \\
\text { concentrations }(\mu \mathrm{g})\end{array}$ & $\begin{array}{c}\text { Initial spore concentration } \\
\log (\mathbf{s p o r e} / \mathbf{m L})\end{array}$ & $\begin{array}{c}\text { Spore counts after } \\
\text { treatment } \mathbf{l o g}(\mathbf{s p o r e} / \mathbf{m L})\end{array}$ & $\begin{array}{c}\text { Reduction per mL } \\
\log (\mathbf{s p o r e} / \mathbf{m L})\end{array}$ \\
\hline 4600 & 5 & 4.097 & 4.942 \\
2300 & 5 & 2.708 & 4.998 \\
1150 & 5 & 2.223 & 4.999 \\
575 & 5 & 1.000 & 5.000 \\
287.5 & 5 & 0.000 & 5.000 \\
143.75 & 5 & 0.000 & 5.000 \\
71.88 & 5 & 0.000 & 5.000 \\
35.94 & 5 & 0.000 & $5.92 \mu \mathrm{g}$ \\
\hline
\end{tabular}

Table 6 Dose response effects of nitric acid, peracetic acid and nitric acid-peracetic acid combinations on spores of $A$. flavithermus DSM $2641^{\mathrm{T}}$ and $G$. thermodenitrificans DSM $465^{\mathrm{T}}$ strains

\begin{tabular}{|c|c|c|c|c|c|}
\hline \multicolumn{6}{|c|}{ A. flavithermus DSM $2641^{\mathrm{T}}$} \\
\hline Nitric acid concentrations $(\mu \mathrm{g})$ & $\begin{array}{c}\text { Nitric acid } \\
\text { dose-response } \\
\text { effect }\end{array}$ & $\begin{array}{c}\text { Peracetic acid } \\
\text { concentrations } \\
(\mu \mathrm{g})\end{array}$ & $\begin{array}{l}\text { Peracetic acid dose- } \\
\text { response effect }\end{array}$ & $\begin{array}{l}\text { Nitric acid- } \\
\text { Peracetic acid } \\
\text { combinations }\end{array}$ & $\begin{array}{c}\text { Combined dose-response } \\
\text { effect }\end{array}$ \\
\hline 33.12 & 0.900 & 35.94 & 0.770 & $1: 1$ & 0.954 \\
\hline 66.23 & 0.910 & 71.88 & 0.880 & $1: 2$ & 0.968 \\
\hline 132.47 & 0.925 & 143.75 & 0.997 & $2: 1$ & 0.943 \\
\hline 264.94 & 0.966 & 287.5 & 0.999 & $1: 3$ & 0.917 \\
\hline 529.88 & 0.988 & 575 & 0.999 & $3: 1$ & 0.931 \\
\hline 2119.5 & 1,000 & 2300 & 1.000 & $4: 1$ & 0.790 \\
\hline 4239 & 1.000 & 4600 & 1.000 & & \\
\hline \multicolumn{6}{|c|}{ G. thermodenitrificans DSM $465^{\mathrm{T}}$} \\
\hline 33.12 & 0.790 & 35.94 & 0.875 & $1: 1$ & 0.984 \\
\hline 66.23 & 0.977 & 71.88 & 0.995 & $1: 2$ & 0.989 \\
\hline 132.47 & 0.994 & 143.75 & 0.998 & $2: 1$ & 0.990 \\
\hline 264.94 & 0.996 & 28.50 & 1.000 & $1: 3$ & 0.990 \\
\hline 529.88 & 1.000 & 575 & 1.000 & $3: 1$ & 0.992 \\
\hline 2119.5 & 1.000 & 2300 & 1.000 & $4: 1$ & 0.993 \\
\hline 4239 & 1.000 & 4600 & 1.000 & & \\
\hline
\end{tabular}

When the dose-response curve is evaluated, the slope of the curve obtained with the dual treatment of agents for A. flavithermus DSM $2641^{\mathrm{T}}$ spores is closer to peracetic acid, which shows that peracetic acid is more effective on spores of this strain (Figure 1a). The points in figure 1b indicate each combination that shows significant interaction. The fact that these points are on the left side of the reference line (CI; combination index <1) indicates the synergism. In the elimination of $A$ flavithermus DSM $2641^{\mathrm{T}}$ spores, there is a clear synergetic interaction in the combination ratios, except for 1:3, and 4:1 ratios (near the additive effect), (Figure 1b).

a)

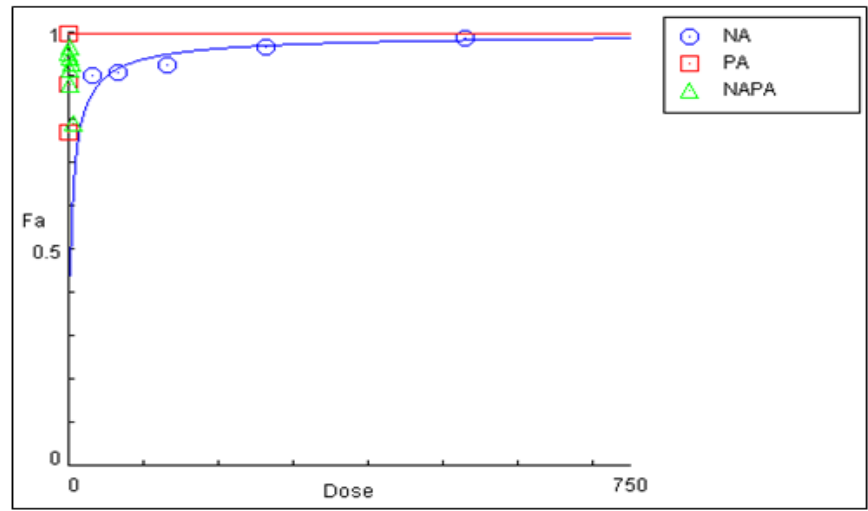

b)

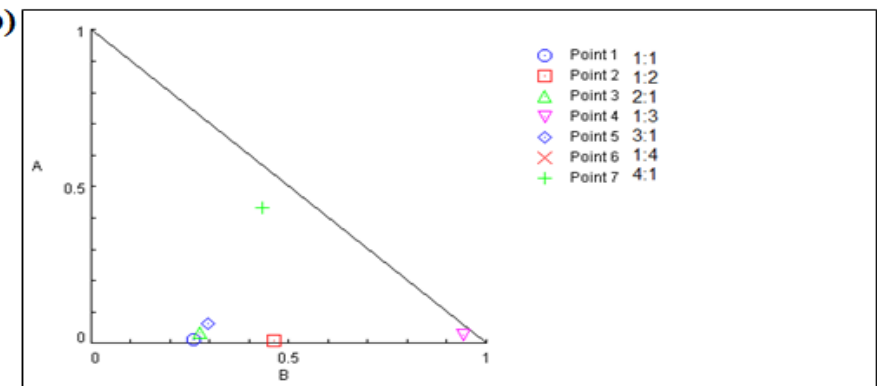

Figure 1 a) Dose response combination curve of Nitric acid, peracetic acid and nitric acid- peracetic acid (A. flavithermus DSM 2641 ${ }^{\mathrm{T}}$ ) NA; nitric acid, PA; peracetic acid; NAPA; Nitric acid and peracetic acid combination. b) Isobologram of nitric acid-peracetic acid combinations. (A. flavithermus DSM 2641 ${ }^{\mathrm{T}}$ )

When evaluating the dose-response curve for G. thermodenitrificans DSM $465^{\mathrm{T}}$ peracetic acid was again found to be more effective in eliminating spores with a combination of dual agents. The combined treatment appears to be closer to the peracetic acid slope (Figure 2a). For G. thermodenitrificans DSM $465^{\mathrm{T}}$, it was revealed that there is a synergetic interaction in the sporicidal agent combinations (except 1:4, 1:3). The points in the graph indicate each combination that shows significant interaction. The fact that these points are on the left side of the reference line $(\mathrm{CI}$; combination index $<1)$ that displays the synergism. The 1:4 combination indicates a close additive effect, while the 1:3 combination shows a sligh antagonistic interaction (Figure $2 \mathrm{~b}$ ). 


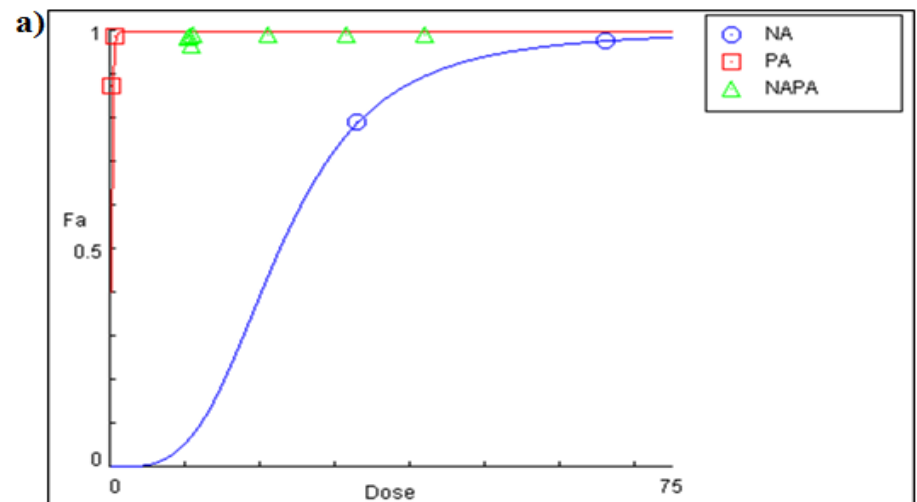

b)

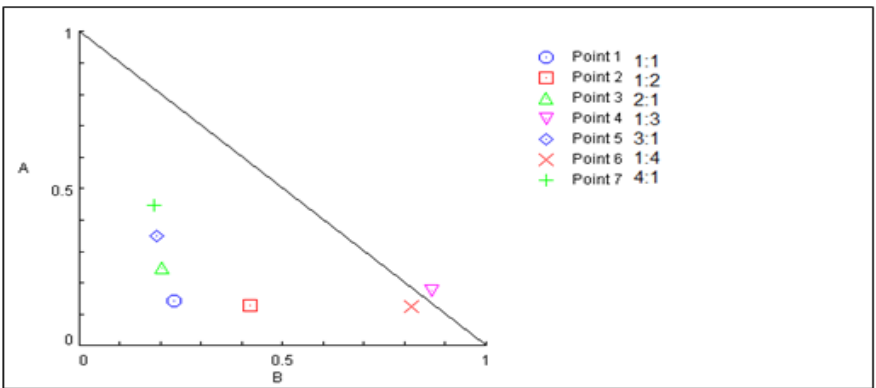

Figure 2 a) Dose response combination curve of Nitric acid, peracetic acid and nitric acid- peracetic acid (G. thermodenitrificans $\mathrm{DSM} 465^{\mathrm{T}}$ ) NA; nitric acid, PA peracetic acid; NAPA; Nitric acid and peracetic acid combination. b) Isobologram of nitric acid-peracetic acid combinations (G. thermodenitrificans DSM $465^{\mathrm{T}}$ )

Bacterial spores are structures that are resistant to chemical agents and physical treatments (Russel, 1990). Examining the studies conducted in the literature, it can be seen that more studies have been conducted on the resistance of mesophilic bacterial spores than thermophilic ones to chemical agents, especially sporicidal agents. For example, Sykes (1990) studied the effects of phenol, chlorhexidine digluconate, glutaraldehyde, hydrochloric acid, chlorine gas releasing compounds and iodine on Bacillus subtilis, Bacillus pumilus and Bacillus stearothermophilus. Briggs and Yazdany (1974) found that chlorocresol and benzalkonium chloride were insufficient to remove B. pumilus and B. stearothermophilus spores. In a study by Young and Setlow (2003), a $3 \log$ decrease in B. subtilis spores was observed when treated with hypochlorite and chlorine dioxide. They also demonstrated that chlorine dioxide has a stronger lethal effect on $B$. subtilis spores than chlorine. Beuchat et al. (2004) also demonstrated that oxidation reactions caused by disinfectants are influenced by organic material in the environment. Moreover, sporicidal agents in the study were tested only on the spores of the mesophilic bacteria according to the literature (Borick, 1968; Briggs and Yazdany, 1974; Russell, 1990; Knott et al., 1995; Sagripanti and Bonifacino, 1996; Young and Setlow, 2003; Beuchat et al., 2004; Maillard, 2011).

According to the spore elimination tests, the spores of G. thermodenitrificans DSM $465^{\mathrm{T}}$ and A. flavithermus DSM $2641^{\mathrm{T}}$ are much more resistant to the chemical agents compared to the spores of G. thermoglucosidans $\mathrm{B} 84 \mathrm{a}$ and $A$. kamchatkensis subsp. asaccharedens F81. Of these agents tested, only peracetic acid, cetylpyridinium chloride and formaldehyde were effective on 4 of the thermophilic bacilli spores. Peracetic acid seems to be one of the ideal sporicidal agents as it was a highly active sporicidal agent besides its economic and health benefits. For example, when comparing chlorhexidine diacetate and nitric acid, which kills all thermophilic spores except spores of $G$. thermodenitrificans DSM $465^{\mathrm{T}}$, chlorhexidine diacetate was found to be costly for clean-in-place procedures. It was found that $4.0 \%$ peracetic acid, which acts on the spores of 4 thermophilic species, and 3\% nitric acid, which eliminates all spores except $G$. thermodenitrificans DSM $465^{\mathrm{T}}$ spores $(99.998 \%)$, are ideal agents due to their lowest contact time and concentration. Peracetic acid allows for time and cost savings as it is degradable, non-toxic and does not require rinsing after treatment (Block, 2001). Alternatively, nitric acid is the most commonly used acid in cleanin-place systems, especially in the dairy industry (Bremer et al., 2006). Moreover, in this study, the exact effective doses of these two sporicidal agents were determined by testing them on 4 thermophilic spores belonging to different species. It was found that the combined application of peracetic acid and nitric acid in the dairy industry is an ideal solution for the elimination of thermophilic spores, considering the recommended application concentrations. a)

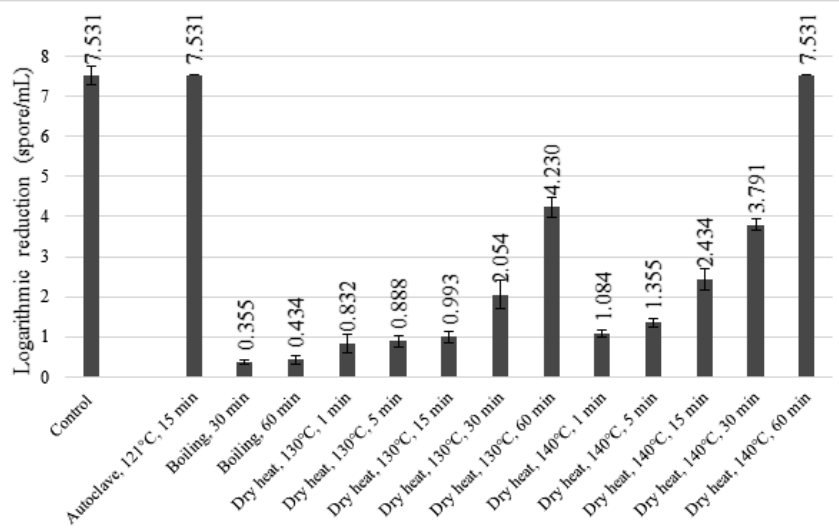

b)

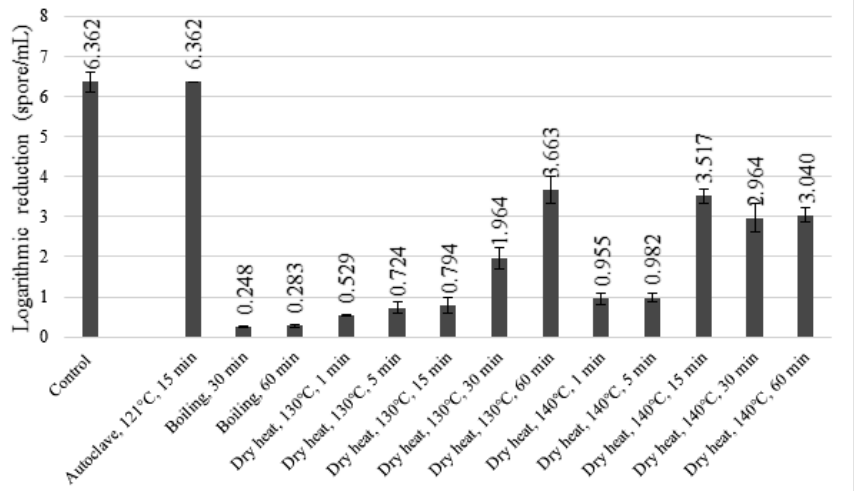

Figure 3 a) Thermal inactivation of A. flavithermus DSM $2641^{\mathrm{T}}$ planktonic spores b) Thermal inactivation of $A$. flavithermus DSM $2641^{\mathrm{T}}$ biofilm spores. Bars represented as logarithmic reduction

\section{Thermal inactivation of thermophilic spores}

The effects of thermal inactivation on the spores of A. flavithermus DSM $2641^{\mathrm{T}}$ and G. thermodenitrificans DSM $465^{\mathrm{T}}$ in both the planktonic phase and biofilm are shown in figure 3 and 4. Complete elimination of A. flavithermus DSM 2641 biofilm spores was only possible by autoclaving. Dry temperature treatment (60 min) at $140{ }^{\circ} \mathrm{C}$ was able to eliminate all planktonic spores. According to these results, it was revealed that planktonic spores of this strain were more resistant to thermal treatments as much as spores in biofilm (Figure 3). Spores of $G$. thermodenitrificans DSM $465^{\mathrm{T}}$ could be completely removed only after sterilization in autoclave, as was found for A. flavithermus DSM $2641^{\mathrm{T}}$. The planktonic spores of this strain have a lower thermal resistance than the planktonic spores of A. flavithermus DSM $2641^{\mathrm{T}}$, because the planktonic spores of $G$. thermodenitrificans DSM $465^{\mathrm{T}}$ can be eliminated during dry temperature treatment $(60 \mathrm{~min})$ at $130^{\circ} \mathrm{C}$. Results in figure 3 and 4 were illustrated as logarithmic reduction. 
a)

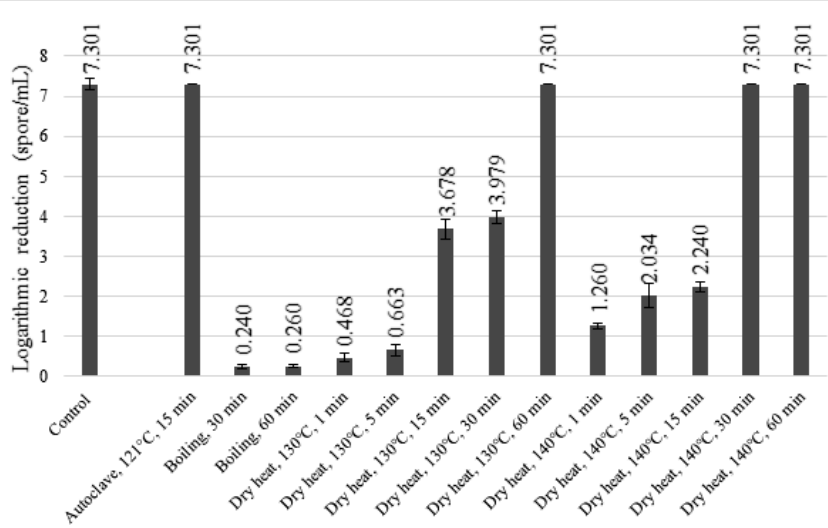

b)

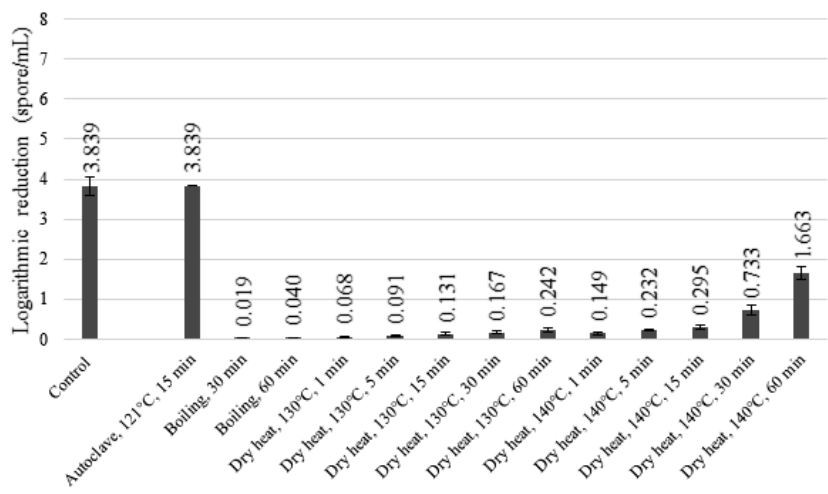

Figure 4 a) Thermal inactivation of G. thermodenitrificans DSM $465^{\mathrm{T}}$ planktonic spores b) Thermal inactivation of $G$. thermodenitrificans DSM $465^{\mathrm{T}}$ biofilm spores. Bars represented as logarithmic reduction

Recently, many studies have been conducted to define the thermal inactivation kinetics of bacterial spores (Witthuhn et al., 2011; Gómez-Jódar et al., 2016; Stoeckel et al., 2016; Den Besten et al., 2018). Thermophilic spores can be effectively eliminated by UHT $\left(>135^{\circ} \mathrm{C}\right)$. However, this heat treatment reduces the valuable content of whey proteins (Elliott et al., 2005). Another increasing problem is the coagulation of concentrated milk or whey due to protein aggregation (Havea et al., 2009; Dumpler and Kulozik, 2015). The k-casein in milk and dairy products breaks down into concentration factors at high temperatures (Anema, 1998). In concentrated whey products, cross-linking between proteins occurs depending on the $\mathrm{pH}$ of the medium and the mineral composition (Havea et al., 2002). When casein micelles interact with denatured whey proteins, gel formation occurs at high temperatures, and this viscous content makes it difficult to eliminate bacterial spores. Wedel et al. (2018) showed that heat treatment for A. flavithermus at $110{ }^{\circ} \mathrm{C}$ for $30 \mathrm{~min}$ is sufficient to inactivate all spores. However, they observed that another strain of A. flavithermus used in the same study remained alive after exposure to $125^{\circ} \mathrm{C}$ for $30 \mathrm{~min}$. Thus, it was clear that thermal resistance also varied at the strain level. When the results of the current study are compared with those of Wedel et al. (2018), it is clear that strain A. flavithermus DSM $2641^{\mathrm{T}}$ was found to be more resistant to prolonged exposure to high temperatures. In a study by Sadiq et al., (2016), $1.5 \log$ decrease was observed at $110^{\circ} \mathrm{C}$ for $30 \mathrm{~min}$. However, the exposure of thermophilic spores to heat treatment was performed only in water. Wells-Bennik et al., (2018) suggested that food ingredients such as proteins and minerals and acidity or alkalinity of food are effective in thermal spore inactivation. In another study with A. flavithermus and G. stearothermophilus, the spore concentration decreased from $6.36-\log$ to $3.72-\log$ at $121^{\circ} \mathrm{C}$ for $15 \mathrm{sec}$. Since G. thermodenitrificans DSM $465^{\mathrm{T}}$ strain evaluated within the scope of this study was removed only by autoclaving process at $121{ }^{\circ} \mathrm{C}$ for $15 \mathrm{~min}$, and dry heat treatment at $140{ }^{\circ} \mathrm{C}(30$ and $60 \mathrm{~min})$, it has been understood that the spores of this strain were more resistant to heat treatment than other bacilli evaluated in the literature. The fact that the A. flavithermus and G. thermodenitrificans spores evaluated in the study cannot be eliminated even at the temperatures used in UHT technology proves why thermophilic bacilli cause continuous contamination in the dairy industry. Another striking result in the study is that the biofilm spores of thermophilic bacilli in the presence of milk residues can only be removed by autoclaving. This makes it impossible to eliminate these spores in dairy environments by thermal treatment.

\section{CONCLUSION}

In this study, the recommended sporicidal treatments for the elimination of bacterial spores posing a risk in the dairy industry were comparatively evaluated.
It was found that simultaneous treatment with widely used agents such as peracetic acid and nitric acid gave much more effective results against these extremely difficult to eliminate spores. It was revealed that these two agents, which are also widely used in the dairy industry, have synergistic interactions due to their low cost and health safety, and can be used at much lower doses through a combination treatment. In this study, it became clear that there are synergistic interactions between widely used sporicidal agents. Therefore, combined treatment with sporicidal agents can be considered as an alternative for the elimination of thermophilic spores in the dairy industry. It has also been recognized that thermophilic spores cannot be eliminated even at the processing temperatures used in the dairy industry, especially if they are in biofilm structures.

Acknowledgments: The authors declare that they have no conflict of interest. This research was supported from The Scientific and Technical Research Council of Turkey (TÜBITAK) by the project number of $116 Z 422$.

\section{REFERENCES}

Anema, S. G. (1998). Effect of milk concentration on heat-induced, pH-dependent dissociation of casein from micelles in reconstituted skim milk at temperatures between 20 and $120^{\circ} \mathrm{C}$. Journal of Agricultural and Food Chemistry, 46(6), 22992305. https://doi.org/10.1021/jf970909+

Banner, M. J. (1995). The selection of disinfectants for use in food hygiene. In Handbook of biocide and preservative use (pp. 315-333). Springer, Dordrecht.

Beaman, T. C., Greenamyre, J. T., Corner, T. R., Pankratz, H. S., \& Gerhardt, P. (1982). Bacterial spore heat resistance correlated with water content, wet density, and protoplast/sporoplast volume ratio. Journal of Bacteriology, 150(2), 870-877. https://doi.org/10.1128/jb.150.2.870-877.1982

Beuchat, L. R., Pettigrew, C. A., Tremblay, M. E., Roselle, B. J., \& Scouten, A. J. (2004). Lethality of chlorine, chlorine dioxide, and a commercial fruit and vegetable sanitizer to vegetative cells and spores of Bacillus cereus and spores of Bacillus thuringiensis. Journal of Food Protection, 67(8), 1702-1708. https://doi.org/10.4315/0362-028X-67.8.1702

Block, S. S. (Ed.). (2001). Disinfection, sterilization, and preservation (pp. 185 204). Lippincott Williams \& Wilkins.

Borick, P. M. (1968). Chemical sterilizers (chemosterilizers). Advances in Applied Microbiology, 10, 291-312. https://doi.org/10.1016/S0065-2164(08)70195-3

Bremer, P. J., Fillery, S., \& McQuillan, A. J. (2006). Laboratory scale Clean-InPlace (CIP) studies on the effectiveness of different caustic and acid wash steps on the removal of dairy biofilms. International Journal of Food Microbiology, 106(3), 254-262. https://doi.org/10.1016/j.ijfoodmicro.2005.07.004

Briggs, A., \& Yazdany, S. (1974). Resistance of Bacillus spores to combined sporicidal treatments. Journal of Applied Bacteriology, 37(4), 623-631. https://doi.org/10.1111/j.1365-2672.1974.tb00486.x

Brooks, J. D., \& Flint, S. H. (2008). Biofilms in the food industry: problems and potential solutions. International Journal of Food Science \& Technology, 43(12), 2163-2176. https://doi.org/10.1111/j.1365-2621.2008.01839.x

Burgess, S. A., Brooks, J. D., Rakonjac, J., Walker, K. M., \& Flint, S. H. (2009). The formation of spores in biofilms of Anoxybacillus flavithermus. Journal of Applied Microbiology, 107(3), 1012-1018. https://doi.org/10.1111/j.13652672.2009.04282.x

Burgess, S. A., Lindsay, D., \& Flint, S. H. (2010). Thermophilic bacilli and their importance in dairy processing. International Journal of Food Microbiology, 144(2), 215-225. https://doi.org/10.1016/j.ijfoodmicro.2010.09.027

Chou, T. C. (2010). Drug combination studies and their synergy quantification using the Chou-Talalay method. Cancer Research, 70(2), 440-446. https://doi.org/10.1158/0008-5472.CAN-09-1947

Cooney, P. H., \& Freese, E. (1976). Commitment to sporulation in Bacillus megaterium and uptake of specific compounds. Microbiology, 95(2), 381-390. https://doi.org/10.1099/00221287-95-2-381

Dumpler, J., \& Kulozik, U. (2015). Heat stability of concentrated skim milk as a function of heating time and temperature on a laboratory scale-Improved methodology and kinetic relationship. International Dairy Journal, 49, 111-117. https://doi.org/10.1016/j.idairyj.2015.05.005

Den Besten, H.M., Wells-Bennik, M.H., \& Zwietering, M.H. (2018). Natural diversity in heat resistance of bacteria and bacterial spores: impact on food safety and quality. Annual Reviews of Food Science and Technology, 9, 383-410. https://doi.org/10.1146/annurev-food-030117-012808

de Vries, Y. P., Hornstra, L. M., de Vos, W. M., \& A bee, T. (2004). Growth and sporulation of Bacillus cereus ATCC 14579 under defined conditions: temporal expression of genes for key sigma factors. Applied and Environmental Microbiology, 70(4), 2514-2519.https://doi.org/10.1128/AEM.70.4.2514$\underline{2519.2004}$

Donnellan, J. E., Nags, E. H., \& Levinson, H. S. (1964). Chemically defined, synthetic media for sporulation and for germination and growth of Bacillus subtilis. Journal of Bacteriology, 87(2), 332-336. https://doi.org/10.1128/jb.87.2.332336.1964 
Elliott, A. J., Datta, N., Amenu, B., \& Deeth, H. C. (2005). Heat-induced and other chemical changes in commercial UHT milks. The Journal of Dairy Research, 72(4), 442-446. https://doi.org/10.1017/S002202990500138X

Flint, S. H., Bremer, P. J., \& Brooks, J. D. (1997). Biofilms in dairy manufacturing plant-description, current concerns and methods of control. Biofouling, 11(1), 8197. https://doi.org/10.1080/08927019709378321

Flint, S., Palmer, J., Bloemen, K., Brooks, J., \& Crawford, R. (2001a). The growth of Bacillus stearothermophilus on stainless steel. Journal of Applied Microbiology, 90(2), 151-157. https://doi.org/10.1046/j.1365-2672.2001.01215.x

Flint, S. H., Ward, L. J., \& Walker, K. M. (2001b). Functional grouping of thermophilic Bacillus strains using amplification profiles of the $16 \mathrm{~S}-23 \mathrm{~S}$ internal spacer region. Systematic and Applied Microbiology, 24(4), 539-548. https://doi.org/10.1078/0723-2020-00081

Gómez-Jódar, I., Ros-Chumillas, M., \& Palop, A. (2016). Effect of heating rate on highly heat-resistant spore-forming microorganisms. Food Science and Technology International,

https://doi.org/10.1177/1082013215580494

Havea, P., Singh, H., \& Creamer, L. K. (2002). Heat-induced aggregation of whey proteins: comparison of cheese WPC with acid WPC and relevance of mineral composition. Journal of Agricultural and Food Chemistry, 50(16), 4674-4681. https://doi.org/10.1021/jf011583e

Havea, P., Watkinson, P., \& Kuhn-Sherlock, B. (2009). Heat-induced whey protein gels: Protein- protein interactions and functional properties. Journal of Agricultural and Food Chemistry, 57(4), 1506-1512. https://doi.org/10.1021/if802559z

Hinton, A. R., Trinh, K. T., Brooks, J. D., \& Manderson, G. J. (2002). Thermophile survival in milk fouling and on stainless steel during cleaning. Food and $\begin{array}{llll}\text { Bioproducts } & \text { Processing, } & \text { 80(4), } & \text { 299-304. }\end{array}$ https://doi.org/10.1205/096030802321154817

Hood, S. K., \& Zottola, E. A. (1995). Biofilms in food processing. Food Control, 6(1), 9-18. https://doi.org/10.1016/0956-7135(95)91449-U

Husmark, U., \& Rönner, U. (1992). The influence of hydrophobic, electrostatic and morphologic properties on the adhesion of Bacillus spores. Biofouling, 5(4), 335-344. https://doi.org/10.1080/08927019209378253

Karaca, B., Buzrul, S., \& Coleri Cihan, A. (2019). Anoxybacillus and Geobacillus biofilms in the dairy industry: effects of surface material, incubation temperature and milk type. Biofouling, 35(5), 551-560. https://doi.org/10.1080/08927014.2019.1628221

Karaca, B., \& Cihan, A. C. (2020). The potential thermophilic Bacilli contaminants for dairy industry. Natural and Engineering Sciences, 5(2), 53-67. https://doi.org/10.28978/nesciences.756754

Kaul, A., \& Singh, R. S. (1982). Production of stable Bacillus stearothermophilus spores. Journal of Food Protection, 45(9), 795-796. https://doi.org/10.4315/0362028X-45.9.795

Kepner, R. L., \& Pratt, J. R. (1994). Use of fluorochromes for direct enumeration of total bacteria in environmental samples: past and present. Microbiological Reviews, 58(4), 603-615.https://doi.org/10.1128/mr.58.4.603-615.1994

Knott, A. G., Dancer, B. N., Hann, A. C., \& Russell, A. D. (1997). Non-variable sources of pure water and the germination and outgrowth of Bacillus subtilis spores. Journal of Applied Microbiology, 82(2), 267-272. https://doi.org/10.1111/j.1365-2672.1997.tb03583.x

Maillard, J. Y. (2011). Innate resistance to sporicides and potential failure to decontaminate. Journal of Hospital Infection, 77(3), 204-209. https://doi.org/10.1016/j.jhin.2010.06.028

Marchand, S., De Block, J., De Jonghe, V., Coorevits, A., Heyndrickx, M., \& Herman, L. (2012). Biofilm formation in milk production and processing environments; influence on milk quality and safety. Comprehensive Reviews in Food Science and Food Safety, 11(2), 133-147. https://doi.org/10.1111/j.15414337.2011.00183.x

Muir, D. D., Griffiths, M. W., Phillips, J. D., Sweetsur, A. W. M., \& West, I. G. (1986). Effect of the bacterial quality of raw milk on the bacterial quality and some other properties of low-heat and high-heat dried milk. International Journal of Dairy Technology, 39(4), 115-118. https://doi.org/10.1111/j.14710307.1986.tb02394.x

Murphy, P. M., Lynch, D., \& Kelly, P. M. (1999). Growth of thermophilic spore forming bacilli in milk during the manufacture of low heat powders. International Journal of Dairy Technology, 52(2), 45-50. https://doi.org/10.1111/j.14710307.1999.tb02069.x

Palmer, J. S., Flint, S. H., Schmid, J., \& Brooks, J. D. (2010). The role of surface charge and hydrophobicity in the attachment of Anoxybacillus flavithermus isolated from milk powder. Journal of Industrial Microbiology and Biotechnology, 37(11), 1111-1119. https://doi.org/10.1007/s10295-010-0758-x

Parkar, S. G., Flint, S. H., Palmer, J. S., \& Brooks, J. D. (2001). Factors influencing attachment of thermophilic bacilli to stainless steel. Journal of Applied Microbiology, 90(6), 901-908. https://doi.org/10.1046/j.1365-2672.2001.01323.x Parkar, S. G., Flint, S. H., \& Brooks, J. D. (2004). Evaluation of the effect of cleaning regimes on biofilms of thermophilic bacilli on stainless steel. Journal of Applied Microbiology, 96(1), 110-116. https://doi.org/10.1046/j.13652672.2003.02136.x
Refstrup, E. (2000). Evaporation and drying technology developments. International Journal of Dairy Technology, 53(4), 163-167. https://doi.org/10.1111/j.1471-0307.2000.tb02900.x

Ronimus, R. S., Parker, L. E., Turner, N., Poudel, S., Rückert, A., \& Morgan, H. W. (2003). A RAPD-based comparison of thermophilic bacilli from milk powders. International Journal of Food Microbiology, 85(1-2), 45-61. https://doi.org/10.1016/S0168-1605(02)00480-4

Russell, A. D. (1990). Bacterial spores and chemical sporicidal agents. Clinical Microbiology Reviews, 3(2), 99-119. https://doi.org/10.1128/CMR.3.2.99

Russell, A. D. (1998). Assesssment of sporicidal efficacy. International Biodeterioration \& Biodegradation, 41(3-4), 281-287. https://doi.org/10.1016/S0964-8305(98)00019-5

Sadiq, F. A., Li, Y., Liu, T., Flint, S., Zhang, G., Yuan, L., \& He, G. (2016). The heat resistance and spoilage potential of aerobic mesophilic and thermophilic spore forming bacteria isolated from Chinese milk powders. International Journal of Food Microbiology, 238(2016),

https://doi.org/10.1016/j.ijfoodmicro.2016.09.009

Sagripanti, J. L., \& Bonifacino, A. (1996). Comparative sporicidal effect of liquid chemical germicides on three medical devices contaminated with spores of Bacillus subtilis. American Journal of Infection Control, 24(5), 364-371. https://doi.org/10.1016/S0196-6553(96)90024-3

Scott, S. A., Brooks, J. D., Rakonjac, J., Walker, K. M., \& Flint, S. H. (2007). The formation of thermophilic spores during the manufacture of whole milk powder. International Journal of Dairy Technology, 60(2), 109-117. https://doi.org/10.1111/j.1471-0307.2007.00309.x

Seale, R. B., Flint, S. H., McQuillan, A. J., \& Bremer, P. J. (2008). Recovery of spores from thermophilic dairy bacilli and effects of their surface characteristics on attachment to different surfaces. Applied and Environmental Microbiology, 74(3), 731-737. https://doi.org/10.1128/AEM.01725-07

Setlow, P. (2007). I will survive: DNA protection in bacterial spores. Trends in Microbiology, 15(4), 172-180. https://doi.org/10.1016/j.tim.2007.02.004

Stickler, D. J. (1997). Chemical and physical methods of biofilm control. In Biofilms: Community Interactions and Control (pp. 215-225). BioLine.

Stoeckel, M., Lücking, G., Ehling-Schulz, M., Atamer, Z., \& Hinrichs, J. (2016) Bacterial spores isolated from ingredients, intermediate and final products obtained from dairies: thermal resistance in milk. Dairy Science \& Technology, 96(4), 569577. https://doi.org/10.1007/s13594-016-0279-0

Sykes, G. (1970). (Symposium on Bacterial Spores: Paper XII) The Sporicidal Properties of Chemical Disinfectants. Journal of Applied Bacteriology, 33(1), 147156. https://doi.org/10.1111/j.1365-2672.1970.tb05240.x

Te Giffel, M. C., Beumer, R. R., Van Dam, W. F., Slaghuis, B. A., \& Rombouts, F. M. (1995). Sporicidal effect of disinfectants on Bacillus cereus isolated from the milk processing environment. International Biodeterioration \& Biodegradation, 36(3-4), 421-430. https://doi.org/10.1016/0964-8305(95)00104-2

Turkiewicz, B., Rucka, M., Poźniak, G., \& Zboińska, E. (2006). Biofunctional membranes from poly (2,6-dimethyl-1,4-phenylene oxide) with self-cleaning properties. Enzyme and Microbial Technology, 39(4), 527-530. https://doi.org/10.1016/j.enzmictec.2004.08.046

Vinter, V. (1970). (Symposium on Bacterial Spores: Paper V). Germination and Outgrowth: Effect of Inhibitors. Journal of Applied Bacteriology, 33(1), 50-59. https://doi.org/10.1111/j.1365-2672.1970.tb05233.x

Warriner, K., \& Waites, W. M. (1999). Enhanced sporulation in Bacillus subtilis grown on medium containing glucose: ribose. Letters in Applied Microbiology, 29(2), 97-102. https://doi.org/10.1046/j.1365-2672.1999.00593.x

Wedel, C., Wunsch, A., Wenning, M., Dettling, A., Kayser, K. H., Lehner, W. D., \& Hinrichs, J. (2018). Thermal treatment of skim milk concentrates in a novel shear-heating device: Reduction of thermophilic spores and physical properties.
Food
Research
International,
107.
$19-26$.

https://doi.org/10.1016/j.foodres.2018.02.005

Wells-Bennik, M. H., Janssen, P. W., Klaus, V., Yang, C., Zwietering, M. H., \& Den Besten, H. M. (2019). Heat resistance of spores of 18 strains of Geobacillus stearothermophilus and impact of culturing conditions. International Journal of
Food
Microbiology,
291(2019),
$161-172$

https://doi.org/10.1016/j.ijfoodmicro.2018.11.005

Whitehead, K. A., \& Verran, J. (2007). The effect of surface properties and application method on the retention of Pseudomonas aeruginosa on uncoated and titanium-coated stainless steel. International Biodeterioration \& Biodegradation, 60(2), 74-80. https://doi.org/10.1016/j.ibiod.2006.11.009

Witthuhn, M., Luecking, G., Atamer, Z., Ehling-Schulz, M., \& Hinrichs, J. (2011) Thermal resistance of aerobic spore formers isolated from food products. International Journal of Dairy Technology, 64(4), 486-493. https://doi.org/10.1111/j.1471-0307.2011.00706.x

Young, S. B., \& Setlow, P. (2003). Mechanisms of killing of Bacillus subtilis spores by hypochlorite and chlorine dioxide. Journal of Applied Microbiology, 95(1), 54-67. https://doi.org/10.1046/j.1365-2672.2003.01960.x

Yuan, D. D., Liu, G. C., Ren, D. Y., Zhang, D., Zhao, L., Kan, C. P., \& Zhang, L. B. (2012). A survey on occurrence of thermophilic bacilli in commercial milk powders in China. Food Control, 25(2), $752-757$. https://doi.org/10.1016/j.foodcont.2011.12.020 
